\title{
PELO DIREITO DE IR E VIR NA CIDADE: MOBILIDADE URBANA E INCLUSÃO SOCIAL EM CIDADE PRAIA - NATAL/RN
}

\author{
Juciara Conceição de Freitas Assunção \\ Especialista em Educação Profissional Técnica de Nível Médio Integrada ao Ensino Médio \\ na modalidade Educação de Jovens e Adultos - PROEJA; Licenciada em Geografia pelo \\ CEFET-RN; Licenciada em Ciências Sociais pela UFRN \\ juciarafreitas@hotmail.com \\ Maria Cristina Cavalcanti Araújo \\ Graduada em Geografia e Mestre em Arquitetura e Urbanismo - UFRN. Professora de \\ Geografia do CEFET-RN. \\ mariacristina@cefetrn.br
}

\begin{abstract}
RESUMO
Este trabalho tem como tema o fenômeno da mobilidade urbana e sua importância para a inclusão social na sociedade contemporânea. Tem como referência de análise a localidade de Cidade Praia, situada no bairro Lagoa Azul, Natal - RN. É um dos bairros mais populosos da cidade e predomina a função residencial, uma vez que o setor produtivo local não absorve a demanda de mão-de-obra existente, fazendo com que a população economicamente ativa se desloque, diariamente, para outras áreas que apresentam maior dinamismo econômico. Nesse sentido, foi realizada pesquisa de campo cuja análise aponta que a mobilidade urbana não determina a condição de exclusão social de determinado grupo de pessoas, mas se constitui em uma das ferramentas para superação dessa condição. Dessa forma, esta pode ser considerada uma das cinco bases da inclusão social, ou seja, as políticas de inclusão devem agregar além das políticas de emprego e renda, saúde, educação e habitação, uma política de mobilidade urbana para que todos possam ter direito à cidade.
\end{abstract}

PALAVRAS-CHAVE: Mobilidade Urbana, Inclusão Social, Espaço Urbano.

\section{FOR THE RIGHT TO GO AND TO COME IN THE CITY: URBAN MOBILITY AND SOCIAL INCLUSION IN CIDADE PRAIA - NATAL/RN}

\begin{abstract}
This work has as subject the phenomenon of urban mobility and its importance for the social inclusion in the contemporary society. Has as analysis reference the locality of Cidade Praia, situated in the district Lagoa Azul, Natal - RN. It is one of the district most populous of the city were predominates the residential function, a time that the local productive sector does not absorb the demand of existing workforce, making with that the economically active population if dislocates, daily, for other areas that present greater economic dynamism. In this direction, field research was carried through whose analysis points that urban mobility does not determine the condition of social exclusion of determined group of people, but if constitutes in one of the tools for overcoming of this condition. In way that this can be considered one of the five bases of the social inclusion, so the inclusion politics must add beyond the politics of job and income, health, education and habitation, one politics of urban mobility so that all can have right to the city.
\end{abstract}

KEY WORDS: Urban Mobility, Social Inclusion, Urban Space. 


\section{PELO DIREITO DE IR E VIR NA CIDADE: MOBILIDADE URBANA E INCLUSÃO SOCIAL EM CIDADE PRAIA - NATAL/RN}

\section{INTRODUÇÃO}

Este trabalho tem como objetivo analisar como as pessoas residentes na localidade de Cidade Praia resolvem seus problemas de mobilidade. Reflete, nesse sentido, sobre a necessidade dos deslocamentos cotidianos dessas pessoas tendo como foco a relação do transporte público com a exclusão social. Dessa forma tornou-se necessária uma articulação teórica das questões pertinentes ao espaço urbano, transporte e inclusão social. O resgate das concepções sobre o tema proposto é muito relevante, pois destaca o espaço urbano como palco das desigualdades socioespaciais e o transporte como um dos elementos fundamentais tanto para o desenvolvimento das cidades quanto para a inclusão social.

A problemática proposta compreende as relações entre a mobilidade urbana e a inclusão social. Nesse intuito serão analisadas as conexões feitas por uma população de baixos rendimentos na realização das atividades urbanas como trabalhar, estudar, cuidar da saúde, fazer compras e lazer. Dessa maneira, foi levantado o seguinte questionamento: qual a importância do sistema de transporte coletivo por ônibus para a população que reside afastada dos espaços de produção e que possui baixos rendimentos? Portanto, a fim de alcançar os objetivos elencados, utilizou-se como metodologia: a pesquisa in loco, o levantamento de dados referentes à caracterização do bairro e de dados relacionados ao serviço de transporte público, e por fim, a aplicação de questionário com a finalidade de obter dados referentes à relação entre o entrevistado residente na localidade e o transporte público.

Assim, este artigo apresenta-se dividido em seis partes. Na primeira parte, é apresentada uma visão geral do trabalho desenvolvido. Na segunda é realizada uma discussão teórica sobre o espaço urbano e a importância do sistema de transporte para a inclusão social. O terceiro tópico apresenta a evolução dos transportes públicos no Brasil e em Natal, tendo como base o trabalho de Lima Neto et al. (2001) e Cascudo (1999). Apresenta uma breve contextualização histórica do desenvolvimento do transporte coletivo no Brasil e em Natal desde os primeiros bondes, o que possibilitou entender o contexto atual. O processo de formação do espaço socioespacial de Cidade Praia, lembrando que este se encontra em um contexto mais amplo, e a análise dos dados coletados entre os moradores dessa localidade sobre a importância do transporte coletivo para o exercício de ir e vir nos espaços da cidade é o que apresentam a quarta e quinta partes deste artigo. Por fim, foram elaboradas considerações sobre as questões referentes à relação entre mobilidade urbana e inclusão socioespacial em Cidade Praia, com a finalidade de aprofundar as discussões sobre o tema.

\section{O ESPAÇO URBANO, MOBILIDADE E EXCLUSÃO SOCIAL}

O conceito de espaço está inserido como um dos principais instrumentos de estudo da geografia enquanto ciência. Dessa forma, considera-se pertinente sua discussão, uma vez que esse trabalho tem como foco o direito de ir e vir no espaço, especificamente no espaço urbano. Partindo do pressuposto de que o uso diferenciado da cidade demonstra que o espaço se constrói e se reproduz de forma desigual e contraditória, ocasionando a 
desigualdade social e, por conseguinte a desigualdade espacial procura-se relacionar a importância da mobilidade urbana como instrumento para a inclusão social.

Ao investigar o espaço faz-se necessário realizar algumas considerações sobre este importante conceito para a Geografia. Para Carlos (2007, p.12), “o espaço surge enquanto nível determinante que esclarece o vivido, na medida em que a sociedade o produz, e nesta condição apropria-se dele e domina-o”.

Tendo como fundamento que o uso do conceito de espaço está “[...] associado indiscriminadamente a diferentes escalas, global, continental, regional, da cidade, do bairro, da casa e de um cômodo no seu interior" (CORRÊA, 1995, p.15). E que o homem constrói o seu próprio espaço dependendo do nível de escala em que esse tenha sido produzido, pretende-se neste artigo trabalhar a escala da localidade Cidade Praia, situada no bairro Lagoa Azul, no município de Natal/RN.

Nesse sentido, nos remetemos a questão de que a dinamicidade do espaço é inerente à dinâmica da sociedade, visto que esta produz seu próprio espaço de acordo com sua realidade. Santos (1978, p. 149) afirma que a dinâmica do espaço, antes de mais nada, lhe assegura "[...] a tendência a reproduzir a estrutura global que lhe deu origem, ao mesmo tempo em que se impõe a essa reprodução social como uma mediação indispensável que às vezes altera o objetivo inicial ou lhe imprime uma orientação particular”.

A concepção de espaço, nessa perspectiva, permite dizer que sua dinâmica é intrínseca às relações sociais estabelecidas, no entanto se faz necessário buscar o conceito de espaço urbano para subsidiar nossa discussão na pesquisa, tendo em vista as transformações espaciais que vêm acontecendo na cidade do Natal. O espaço urbano como produto social caracteriza-se por suas transformações constantes em seu interior refletindo as peculiaridades da sociedade que o habita em determinado momento histórico. Dessa forma, não podemos deixar de abordar esse espaço sob a égide da lógica capitalista. Assim, Corrêa (1989, p.11) conceitua o espaço urbano capitalista como "[...] um produto social, resultado de ações acumuladas através do tempo, e engendradas por agentes que produzem e consomem espaço. [ ] A ação desses agentes é complexa, derivando da dinâmica de acumulação de capital” entre outras variáveis.

Podemos dizer então que o espaço urbano caracteriza-se como produto social em constante transformação, refletindo as características da sociedade capitalista, onde predomina o acesso desigual ao espaço, a segregação socioespacial, o conflito de interesses por parte dos agentes sociais. E que este é produtor e ao mesmo tempo produto das relações capitalistas de produção. Tais características intrínsecas ao espaço urbano se refletem no processo de urbanização.

Segundo Carlos (2007), o acesso ao espaço na cidade está submetido ao mercado, onde a propriedade privada do solo urbano surge como condição do desenvolvimento do capitalismo. A propriedade privada está diretamente relacionada à divisão e parcelamento da cidade, e à profunda desigualdade do processo de produção do espaço urbano, o que se percebe claramente na vida cotidiana.

Grostein (2001) afirma que a dualidade observada nos processos socioespaciais de construção da metrópole contemporânea se expressa no reconhecimento de uma cidade formal adotada pelo poder público, onde se concentram os investimentos urbanos, e de 
outra construída à sua margem, a cidade informal que associa o fenômeno da expansão urbana ilegal ao da exclusão social.

Nessa perspectiva, Rolnik (2004, p. 40) percebe a cidade como "um imenso quebra cabeças [...], onde cada qual conhece seu lugar e se sente estrangeiro nos demais, é a este movimento de separação das classes sociais e funções no espaço urbano que os estudiosos da cidade chamam de segregação espacial”. Entre as cidades que cresceram vertiginosamente na última metade do século XX encontra-se Natal, e ao se visitar a cidade é possível perceber a diferença entre as paisagens, expressando a dualidade na ocupação dos espaços. Já Cidade Praia, nas palavras de Grostein, estaria incluída na parte da cidade informal.

Os muros visíveis e invisíveis que dividem a cidade são evidentes, sendo estes intrínsecos à organização do espaço urbano contemporâneo. A segregação socioespacial se manifesta através dos territórios distintos e separados para cada grupo social, além da separação das funções, principalmente morar e trabalhar, sendo clara a desigualdade de tratamento por parte do Estado. Rolnik (2004, p. 42) ao destacar que “a cena clássica cotidiana das grandes massas se deslocando nos transportes coletivos superlotados ou no trânsito engarrafado são a expressão mais acabada desta separação", nos remete à questão que orienta este trabalho, que se define na questão da mobilidade urbana como instrumento de inclusão social.

Nos últimos cinqüenta anos o processo de urbanização nas cidades brasileiras aumentou consideravelmente, bem como os problemas oriundos a esse processo. E sendo o espaço urbano construído de forma desigual, a oferta de infra-estrutura e serviços básicos à população também são disponibilizados de forma diferenciada. Para a população residente nas áreas periféricas da cidade cabe se deslocar para o centro de produção da cidade através de transporte coletivo, que, apesar de ser considerado como serviço público, tem que ser pago por aqueles que dele necessita.

Os engarrafamentos e a violência no trânsito são as expressões mais visíveis do sistema de circulação, no entanto nossa prioridade neste trabalho é compreender não o sistema técnico em si, mas como pessoas residentes em um bairro periférico experimentam o direito de ir e vir no espaço urbano.

Numa sociedade de mercado ${ }^{1}$, a satisfação das necessidades do trabalhador encontra-se submetida ao lucro. Assim, como qualquer mercadoria, a circulação urbana baseia-se, também, na condição de classe, uma vez que faz parte de um contexto mais amplo, o do espaço urbano capitalista cujo processo de produção se traduz na desigualdade de interesses e oportunidades.

No Brasil, mais da metade dos seus habitantes residem hoje em áreas urbanas, sendo que a maioria das pessoas depende do transporte coletivo para deslocar-se. Assim, o acesso das pessoas às atividades necessárias à vida moderna depende do funcionamento adequado do transporte coletivo. Em áreas isoladas, o transporte coletivo é inclusive uma questão de sobrevivência.

\footnotetext{
${ }^{1}$ Quando os agentes econômicos agem de forma livre, sem a intervenção do Estado.
} 
O Relatório Final sobre Mobilidade e Pobreza do ITRANS (2004, p. 8) ao relacionar a mobilidade urbana e a pobreza assegura que "nem todas as dimensões da pobreza têm sido adequadamente estudadas e mensuradas nas cidades brasileiras [ ]. A mobilidade urbana e a oferta adequada dos serviços públicos de transporte coletivo raramente são estudadas em suas relações com a pobreza (ITRANS,). Ao tratar das dimensões da pobreza, é imprescindível considerar que esta muitas vezes é vista como um problema relacionado à questão econômica, de quanto determinada família dispõe para viver. No entanto, é necessário incluir entre outras variáveis utilizadas na redução da pobreza a oportunidade de ir e vir no espaço urbano. Diante dessa constatação faz-se necessário esclarecer os conceitos pobreza, exclusão social e mobilidade urbana utilizados neste trabalho.

A pobreza, definida pelo Relatório Final - Mobilidade e Pobreza do ITRANS (2004) consiste em situações de carência em que os indivíduos não conseguem manter um padrão mínimo de vida, condizente com as referências socialmente estabelecidas em cada contexto histórico. Mas, acrescenta que definir a pobreza apenas como a insuficiência de renda para que uma família satisfaça suas necessidades básicas é uma abordagem simplificadora. Assim, compartilha a mesma definição de Gomide (2003), que conceitua a pobreza como um fenômeno de várias dimensões, não é apenas insuficiência de renda para que uma família satisfaça suas necessidades, mas também é a privação do acesso aos serviços essenciais como educação, saúde, transporte coletivo, etc. e aos direitos sociais básicos como o trabalho, a moradia, entre outros.

Por sua vez, o conceito de exclusão social estende o conceito de pobreza para além da capacidade de adquirir bens e serviços. A exclusão social inclui, além da insuficiência de renda, a discriminação social, a segregação espacial, a não-eqüidade e a negação dos direitos sociais. Sposati (1998, p.3) considera “que o conceito de exclusão social hoje se confronta diretamente com a concepção de universalidade e com ela a dos direitos sociais e da cidadania. A exclusão é a negação da cidadania" (grifo da autora). Nesse sentido, o conceito de pobreza a ser adotado neste trabalho será entendido em sua forma mais ampla, compreendendo a exclusão social. Enfocar-se-á, dessa maneira, a discussão nas dimensões da pobreza urbana que se referem à privação do acesso aos serviços públicos essenciais, em particular aos serviços públicos de transporte coletivo urbano.

É inegável a diferenciação dos espaços urbanos, todavia quanto mais aumenta a ocupação da periferia mais aumenta a necessidade de deslocamento, e por se constituir como porção ilegal a oferta no setor de transporte público não atende à demanda. É o caso da Zona Norte, região administrativa onde se localiza Cidade Praia, uma vez que esta foi a região que mais cresceu na cidade nos últimos vinte anos, no entanto os investimentos em infraestrutura e serviços públicos não acompanharam proporcionalmente tal expansão.

Assim sendo, a percepção das dimensões da pobreza para além das carências materiais e da insuficiência da renda pode ser alcançada através da noção de modo de vida. O não acesso aos direitos sociais contribui, efetivamente, para a permanência daquela. Como apontam diversos estudos sobre a periferia metropolitana, é nesta onde a pobreza é mais perceptível e consolidada. Nessa perspectiva Santos (2000, p.115) afirma que "morar na periferia é se condenar duas vezes à pobreza. À pobreza gerada pelo modelo econômico, segmentador do mercado de trabalho e das classes sociais, superpõe-se a pobreza gerada pelo modelo territorial”. Uma das conseqüências de se morar na periferia diz respeito a perder oportunidades de emprego, quando o empregador tem que subsidiar os custos dobrados com o transporte do funcionário, se este necessita pagar duas passagens para ir trabalhar, 
entre outros entraves. Os pobres ${ }^{2}$, por viverem na periferia metropolitana, pagam muito mais para ter o direito de circular na cidade. O próprio afastamento do núcleo faz com que a reprodução do seu modo de vida dependa do transporte coletivo.

Não por acaso pesquisas apontam que na parcela da população com renda inferior a três salários mínimos, o acesso ao transporte coletivo constitui-se numa das principais barreiras ao acesso aos espaços da cidade. Esta barreira decorre da insuficiência da renda e do alto valor das tarifas, mas também, da falta de acesso a equipamentos coletivos. Isto para os que trabalham no mercado formal e informal e contam minimamente com algum benefício ou poucos recursos para o deslocamento.

Para os que não tem acesso às oportunidades mínimas de trabalho, advém o fenômeno da mobilidade limitada ou nula apontada por Milton Santos (2000, p. 90). Mobilidade limitada ocasionada pelo precário e/ou ausência de acesso aos meios de transporte, assim como também pela carência de recursos financeiros para as necessidades mais prementes como, por exemplo, deslocar-se até os hospitais especializados ou buscar trabalho nos centros mais afastados do bairro ou do município.

Diante de tantos fatores que provocam e/ou caracterizam a exclusão social e o fato de haver limitações de acesso, remete-nos a entender o conceito de mobilidade e acessibilidade. O termo mobilidade refere-se ao movimento decorrente da necessidade de deslocamento das pessoas no meio urbano (TORQUATO, 2006). De acordo com Vasconcellos (2001), a acessibilidade, medida mais direta dos efeitos de um sistema de transporte, pode ser vista como a facilidade de se atingir os destinos desejados. A acessibilidade pode ser avaliada pelo número e pela natureza dos destinos desejados que possam ser alcançados por uma pessoa, levando-se em conta o tempo e o custo necessário. Este enfoque inclui a análise da conexão entre a oferta do sistema de circulação e a estrutura urbana como elementos interdependentes. Esta definição leva em consideração o indivíduo, permitindo avaliar como ele pode usar o espaço da cidade.

De acordo com Lemos, Santos e Portugal (2004) o conceito de mobilidade consiste na capacidade de um indivíduo se deslocar, envolvendo dois componentes. O primeiro depende do desempenho do sistema de transporte como infra-estrutura de transporte, local onde está a pessoa, a hora do dia e a direção para qual deseja ir. E o segundo componente depende das características do indivíduo e das suas necessidades como renda e tempo. Assim, a acessibilidade está relacionada com a efetividade do sistema de transporte em interligar localidades espacialmente separadas e a mobilidade está associada com até que ponto um determinado indivíduo pode fazer uso do sistema. Esta visão é a que será utilizada neste trabalho.

Ao tratar de tais conceitos, fez-se necessário averiguar o que diz a Constituição Federal em seu artigo 30, onde afirma que o transporte coletivo é um serviço público de caráter essencial. Ao dar este caráter essencial, a Carta Magna afirma que é um serviço fundamental necessário para a concretização das funções sociais da cidade. A localização das funções urbanas (função trabalho e função moradia) pode determinar as características da função circulação. Considerando que a produção do espaço urbano constrói uma relação dialética entre o transporte e a localização das estruturas, é importante que haja um planejamento racional.

\footnotetext{
${ }^{2}$ Expressão utilizada por Santos (2000).
} 
O transporte público, além de ser um componente do sistema de mobilidade urbana, é um importante elemento de combate à pobreza urbana. Dele depende o acesso das populações que não dispõem de meios de transporte motorizados próprios às oportunidades de trabalho, aos equipamentos e serviços sociais como saúde e educação, e às atividades que garantem a dignidade humana e a integração social como o lazer, especialmente as visitas aos amigos e parentes, compras etc. Desse modo, se o serviço não for adequado às necessidades da população, especificamente a mais pobre, ele pode se tornar uma barreira à inclusão social e um impedimento ao acesso às oportunidades e atividades essenciais que a cidade dispõe (GOMIDE, LEITE, REBELO, 2006).

A maioria das cidades de países em desenvolvimento, inclusive as brasileiras, foram adaptadas para o uso eficiente do automóvel, cuja frota vem crescendo acentuadamente nos últimos anos. Em contrapartida, os sistemas de transporte público permaneceram insuficientes para atender a demanda crescente e experimentam um declínio na sua importância, na sua eficiência e confiabilidade. Conseqüentemente, formou-se uma separação entre aqueles que têm acesso ao automóvel e aqueles que dependem do transporte público, refletindo grandes disparidades sociais e econômicas da nossa sociedade. Pois, enquanto uma parcela reduzida desfruta de melhores condições de transporte, a maioria continua limitada nos seus direitos de deslocamento e acessibilidade (ANTP, 1997). Assim, a precariedade na oferta e as altas tarifas do transporte público podem restringir as oportunidades de trabalho dos mais pobres, tanto na procura de emprego quanto no deslocamento ao local de trabalho.

Mediante a carência de acompanhamento da evolução das cidades por parte do Governo, em termos de infra-estrutura e serviços públicos, a criação do Ministério das Cidades com objetivo de integrar a política habitacional, a de transporte e a de saneamento visa ter um alcance social mais abrangente, beneficiando os espaços menos privilegiados. Nessa proposta, no que se refere ao transporte público, a cidade do Natal foi contemplada com o Pró-Transporte que será discutido mais adiante. Porém este se destaca entre os demais programas de mobilidade e acessibilidade previstos para a cidade porque beneficia diretamente a população residente em Cidade Praia.

Diante do exposto, verificamos que o espaço urbano é diferenciado, ou seja, apresenta espaços segregados, e que a mobilidade urbana é um dos fatores que podem contribuir para a inclusão socioespacial. A fim de verificar como se dá esse processo na cidade do Natal se faz necessário um breve resgate histórico da evolução do sistema de transporte na cidade, o qual irá abordar o capítulo a seguir.

\section{EVOLUÇÃO DOS TRANSPORTES PÚBLICOS NO BRASIL E EM NATAL}

A história dos transportes analisada sob diversos aspectos como movimentações de pessoas e mercadorias representa um elemento fundamental da vida social e econômica de uma sociedade. O que permite interpretar a partir de um contexto sócio-econômico a evolução desse setor e compreender como este se organiza na atualidade. Segundo Lima Neto et al (2001) o transporte é uma infra-estrutura complexa que está relacionada aos diferentes momentos da vida social e seu ambiente natural.

Compreender a história dos transportes é entender como as diversas redes espaciais de infra-estruturas, serviços e organizações e respectivas tecnologias resultam e se inserem a padrões atuais de demanda de transportes relacionados com as estruturas demográficas, 
sociais e econômicas. Por ser um sistema que tem como objetivo realizar interações espaciais da sociedade e sua economia, os transportes necessitam em seus estudos a condição de sua natureza geográfica, pois "entender a história dos transportes é compreender as mudanças nas geografias desse sistema e suas dimensões econômicas e políticas” (LIMA NETO et al, 2001, p. 5).

O sistema de transporte, de modo geral, é fundamental para o progresso das cidades, mas é no seu interior, principalmente das médias e grandes cidades, que, silenciosamente se deslocando, as pessoas contribuem com o desenvolvimento da vida social e econômica de suas cidades. Desse modo, pretende-se aqui fazer uma breve análise do desenvolvimento histórico do sistema de transporte coletivo no Brasil para compreender o processo de evolução desse sistema na cidade do Natal assim como também do bairro Lagoa Azul.

No Brasil colonial a provisão de infra-estruturas e serviços de transporte não era reconhecida como função pública, e sim como um empreendimento particular que dependia da aprovação do governo português. Lima Neto et al (2001, p. 86) ao fazer um balanço do período colonial afirma que foram "trezentos anos [que] não deixaram uma grande herança em termos de infra-estrutura”. Após a independência, nas primeiras décadas, as questões urbanas assim como os transportes urbanos não faziam parte das preocupações do Imperador e consistiam como continuidade do que existia no período colonial. Somente em 1930, no Rio de Janeiro capital do Império, iniciou-se o serviço de transporte coletivo.

No período pós-guerra a urbanização da população aumenta pelo fato da industrialização nas cidades atrair migrantes do campo. E com relação aos transportes, grandes mudanças ocorreram por causa da relativa omissão dos poderes públicos com os meios públicos de transporte e também da política a favor do automóvel. Os investidores que dominaram o sistema sobre trilhos se desinteressaram de continuar explorando os bondes e as ferrovias pelo fato de que as cidades estavam crescendo e necessitando de novos investimentos.

Durante o Regime Militar as principais cidades cresceram bastante, produzindo também o crescimento populacional que extrapolavam os limites dos municípios núcleos, "este crescimento refletiu-se, no aumento dos problemas de deslocamentos urbanos, sendo que a maior parte da população era dependente dos meios coletivos, entre os quais predominava o ônibus” (LIMA NETO et al, 2001, p. 379).

Seguindo o raciocínio de que governar é abrir estradas, o pensamento de humanizar as cidades e cuidar de seus problemas de deslocamentos significava construir redes de vias expressas urbanas e viadutos. Apesar da elaboração de um Plano Diretor em algumas cidades, as vias expressas quase nunca seguiam um esquema de planejamento de transportes, as obras aconteciam de acordo com as oportunidades e conveniências políticas locais (LIMA NETO et al, 2001, p. 381).

Com a crise do petróleo, em 1973, o Governo Federal percebeu a fragilidade do modelo rodoviarista e a importância do transporte coletivo. Nesse período o governo assumiu pela primeira vez na história o transporte urbano como prioridade de ação. Assim o GEIPOT (Grupo Executivo para a Integração da Política de Transportes da Empresa Brasileira de Planejamento de Transportes) elaborou o primeiro documento que tratou da questão dos transportes urbanos em termos nacionais (LIMA NETO et al, 2001). Concomitante a esse contexto se desenvolve o sistema de transporte na cidade do Natal que seguindo a 
tendência nacional começa a se preocupar com o deslocamento urbano a partir do século XIX.

Em Natal, no ano de 1884 surgiu o primeiro plano na área do transporte. O presidente da Província, Dr. Francisco de Paula Sales, neste mesmo ano concedeu privilégio a João Avelino Pereira de Vasconcelos para organizar um serviço de trilhos urbanos com a finalidade de transportar passageiros e mercadorias com carros movidos a vapor ou a tração animal. O projeto não se concretizou. "[...] os natalenses continuaram ignorando outro meio de viação urbana além dos dedos dos pés” (CASCUDO, 1999, p. 308).

Apenas no ano de 1890 é que surge a empresa de Carros de Aluguel. Os carros iam do bairro da Ribeira ao bairro da Cidade Alta e serviam para passeios através de contratos. Devido aos valores cobrados o empreendimento não durou um ano (CASCUDO, 1999). No ano de 1908, no dia 29 de março, instalou-se em Natal a Companhia Ferro Carril de Natal, cuja sede se localizava na rua Dr. Barata, esquina com a travessa Aureliano de Medeiros. Os assuntos da cidade, além dos palpites, eram bondes, burros, trilhos, etc. A inauguração do tráfego aconteceu em 7 de setembro de 1908, no trecho da rua Dr. Barata à Praça João Maria (CASCUDO, 1999).

Além da preocupação em investir no transporte das pessoas na cidade, não poderia ser esquecido outras áreas do Estado. Como o vale do Ceará-Mirim se constituía, na época, no maior centro de interesse econômico da Província, a Estrada de Ferro Central do Rio Grande do Norte (EFCRGN) teve autorização para iniciar suas obras desde 1870, mas tal anseio só se materializou em 1906. E assim "atravessava-se o rio Potengí e tomava-se o trem no outro lado na Coroa, onde se construiu uma estaçãozinha” (CASCUDO, 1999, p. 429). O primeiro trecho ferroviário, Coroa ao Ceará-Mirim, foi inaugurado em 13 de junho de 1913. E em 20 de abril de 1916, foi inaugurada a ponte de Igapó.

A ponte de Igapó na época em que foi construída era considerada a maior do Nordeste, o que dava visibilidade à cidade do Natal. Tal empreendimento marca a ligação da atual Zona Norte de Natal às demais áreas da cidade.

Os ônibus na cidade do Natal começaram a trafegar após o Decreto $n^{0}$. 415, de 24 de janeiro de 1929. "Eram dois carros de L. Bezerra de Andrade e Francisco Azevedo Maia" (CASCUDO, 1999, p. 311). Os bondes foram os percussores dos primeiros transportes coletivos sobre rodas pneumáticas. Ao saírem de circulação, possibilitou o surgimento do planejamento do Sistema de Transporte Público de Passageiros em Natal.

Natal não ordenou seu trânsito e sistema de transporte de forma integrada ao planejamento da cidade até a década de 80, o que veio a consolidar um sistema viário estrutural escasso (TORQUATO, 2006). Somente em 1984 foi criada a Superintendência de Transportes Urbanos (STU), órgão responsável pelo sistema viário da cidade. Nesse período foi promulgado o regulamento para a exploração dos serviços de transporte coletivo no município, através do Decreto Municipal $\mathrm{N}^{\circ}$. 2.812 de 01 de julho de 1983. A Superintendência de Transportes Urbanos se transformou em Secretaria de Transporte e Trânsito Urbano (STTU) a partir da implantação do Novo Código de Trânsito Brasileiro que caracteriza o órgão com as funções de fazer cumprir a legislação e as normas do trânsito, operando até o momento atual. 
Na década de 90 a política de transporte não foi priorizada pelo Governo Federal, porém as decisões tomadas pelo governo interferiram, direta e indiretamente, o setor de transportes urbanos, como a política de energia, porque definia o preço dos combustíveis, o financiamento da produção e a taxação para a aquisição de veículos, induzindo ao aumento da taxa de motorização nas cidades e os engarrafamentos (ANTP, 2003 apud TORQUATO, 2006).

Mediante o contexto exposto, atualmente o sistema de transporte coletivo por ônibus em Natal funciona sem licitação, de modo que a regulamentação prevista para a concessão do serviço de transporte coletivo por ônibus foi impedida através de liminar, o que vem a confirmar que apesar de se constituir em serviço público é regido pela lógica do mercado, onde cada empresa quer garantir a sua fatia. Apesar das empresas que operam em Lagoa Azul e, por sua vez, Cidade Praia, fazerem um dos percursos mais longos da cidade, tem como atrativo para permanecerem operando, o lucro propiciado pela quantidade de usuários, visto que atende ao terceiro bairro mais populoso da cidade.

Atualmente sete empresas oferecem o serviço de transporte coletivo, as quais operam com 86 linhas diretas, com uma frota de 712 ônibus, realizando 158.068 viagens por mês, sendo 7.903 viagens por dia útil. O sistema transporta uma média de 10.605 .433 passageiros por mês (NATAL, 2008b).

Com o objetivo de integrar os bairros da Zona Norte foi construído o Terminal de Integração de Soledade I. Em entrevista concedida para este trabalho, Flávio Mota da Nóbrega, chefe do Departamento de Estudos e Projetos da STTU, afirmou que a proposta inicial era funcionar com cinco ônibus circulares em bairros distintos que ao chegarem ao Terminal possibilitaria ao passageiro pegar o ônibus de seu destino. E Cidade Praia seria uma das contempladas com este serviço, mas este foi impedido de funcionar devido a uma liminar que impediu tal ação. Verificamos, assim, uma intervenção motivada por interesses econômicos na prestação de um serviço público, que embora tenha esse caráter é objeto de conflito de interesse por parte do capital, ou seja, das empresas prestadoras do serviço de transporte, evidenciando o viés capitalista.

Ainda com a proposta de integração, a cidade conta com as estações de transferência que permitem aos usuários utilizar a conexão para ir a lugares que seu ônibus não vai pagando somente uma passagem. Nesta proposta o passageiro utiliza o ônibus disponível em seu bairro, desce numa das estações de transferência e pega outro ônibus que vá ao destino desejado e no retorno é possível a mesma conexão. Cabe destacar que esse serviço é ofertado apenas para a modalidade ônibus.

A Oficina Consultores, empresa contratada pela STTU para a reorganização da Rede de Transporte Público de Natal, em 2001 observou que o sistema apresenta desigualdades expressivas no serviço oferecido na cidade no que diz respeito à freqüência, a diversificação dos destinos e a taxa de ocupação do transporte nas viagens (TORQUATO, 2006). Esse sistema de transporte já não atende a demanda, uma vez que concebido há mais de 20 anos não acompanhou a expansão da cidade no mesmo ritmo.

A criação do Estatuto das Cidades $^{3}$, em 2001, incentivou a elaboração de planos de transportes atrelados aos planos diretores. A criação do Ministério das Cidades e da

\footnotetext{
${ }^{3}$ Lei $n^{\circ} .10 .257$, de 10 de julho de 2001. Regulamenta os artigos 182 e 183 da Constituição Federal e estabelece diretrizes gerais da política urbana.
} 
Secretaria Nacional da Mobilidade, em 2003, assim como a realização da Conferência das Cidades e a definição de uma Política Nacional de Desenvolvimento Urbano, demonstra a preocupação do atual Governo Federal com o setor de transportes urbanos.

Em Natal, a Lei Complementar $\mathrm{n}^{0}$. 082 de 21 de junho de 2007, o atual Plano Diretor se constitui como instrumento básico da política de desenvolvimento urbano sustentável do Município. No artigo $2^{\circ}$ apresenta seu principal objetivo que se constitui no "[...] pleno desenvolvimento das funções sociais, e ambientais da cidade e da propriedade, garantindo um uso socialmente justo e ecologicamente equilibrado do seu território”. Entre as funções sociais da cidade foi destacada neste trabalho a mobilidade. Assim, buscamos o que o atual Plano Diretor da cidade do Natal determina sobre esta questão.

O Artigo 57 determina que a Política de Mobilidade Urbana seja instituída pelo Poder Público Municipal no prazo máximo de dois anos. De acordo com Flávio Mota da Nóbrega da STTU o Plano Diretor de Transporte Urbano já entrou em processo de licitação, o que representa o primeiro passo para elaboração deste. E o Artigo 58 trata da Política de Mobilidade Urbana que deverá ser instrumento de inclusão social ampliando a mobilidade da população, promovendo o acesso físico a serviços e equipamentos públicos, ao lazer e a integração social; respeitar o meio ambiente priorizando a utilização de combustível não poluente ou de baixo teor de poluição; preservar e promover a vida aliviando os conflitos e transformando as vias públicas em espaços seguros; promover o desenvolvimento econômico, minimizando desperdícios, racionalizando o transporte e reduzindo custos.

Os planos e projetos específicos de mobilidade urbana, expressos no artigo 59, deverão atender ao Plano Diretor de Mobilidade Urbana considerando, especificamente no que diz respeito ao transporte coletivo: a utilização racional do espaço de circulação urbana através da priorização da circulação de pedestres em relação aos veículos e do transporte coletivo em relação ao transporte individual; o fortalecimento de uma rede de transporte coletivo de qualidade e ambientalmente sustentável e acessíveis aos portadores de deficiência física e mobilidade reduzida, da integração física e tarifária, da melhoria das condições de conforto e segurança nos pontos de parada e da adoção de medidas de incentivo ao uso do sistema de transporte coletivo nos deslocamentos diários; a adequação da rede viária principal com vistas à melhoria do desempenho da rede de transporte coletivo, em termos de rapidez, conforto, segurança e custos operacionais (NATAL, 2007b).

Com relação a este último ponto, que diz respeito à adequação da rede viária principal, se faz necessária uma intervenção urgente, pois Natal possui um volume de tráfego que ultrapassa a capacidade das vias, conforme representado na Figura 01. 


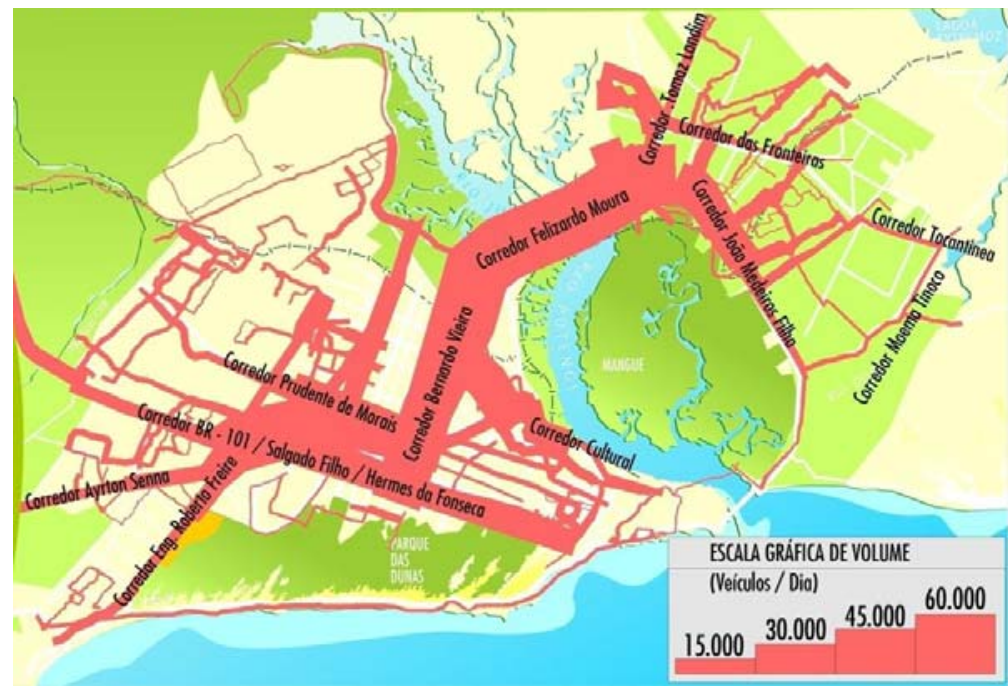

Figura 1: Volume de tráfego em Natal

Fonte: Xavier, 2008

De acordo com a figura acima, verificamos que uma das vias mais comprometidas é a que liga todos os bairros da Zona Norte aos demais espaços da cidade, o corredor Felizardo Moura, fazendo com que a população sofra diariamente com os engarrafamentos, que por sua vez geram outras adversidades, como atraso ao emprego e outros compromissos, poluição atmosférica, desgaste físico da via que exige reparos constantes, cujo valor poderia ser utilizado em outros serviços, entre outras conseqüências.

Em termos práticos, está em andamento o programa Pró-Transporte que está investindo na Zona Norte recursos na ordem de R\$ 72,8 milhões, sendo R\$ 64,9 milhões do governo do Estado e cerca de R\$ 7,8 milhões da Prefeitura do Natal. Apesar de se constituir como obras independentes, o Pró-Transporte vai servir como complemento ao Complexo Viário da Ponte Newton Navarro. Os principais objetivos do Pró-Transporte consistem em agilizar o transporte coletivo com redução de custos para o usuário, reduzir o volume de ônibus na passagem sobre o Rio Potengi e garantir melhor operação para o trem metropolitano.

Não há duvida quanto a importância desse projeto, mas cabe lembrar que a política de mobilidade urbana da cidade do Natal, em termos legais, segue o paradigma do Estatuto das Cidades que se constitui no esforço em viabilizar as mudanças almejadas para as cidades, de modo geral. No entanto, sabemos que o mesmo é o resultado do embate de interesses adversos e pôr em prática o que é estabelecido politicamente representa um grande desafio a ser superado, especificamente no que diz respeito aos interesses econômicos que na maioria das vezes se sobrepõe aos interesses sociais.

Nesse sentido, ao comparar o discurso, o dito e o escrito com a práxis, o real e o cotidiano percebemos que não há sintonia. Há projetos, mas enquanto não se concretizam, os problemas nos deslocamentos diários das pessoas que moram na periferia e dependem do transporte público permanecem. É o que veremos no próximo capítulo.

\section{PELO DIREITO DE IR E VIR NA CIDADE}

Ao procurar compreender as relações entre transporte urbano e inclusão social, faz-se necessário analisar as conexões feitas por uma população de baixos rendimentos na 
realização das atividades inerentes a vida urbana como trabalhar, estudar, cuidar da saúde, fazer compras e lazer. Como a hipótese que norteia este trabalho é de que o acesso às oportunidades urbanas é restrito a população de baixa renda residente em um bairro periférico de Natal, foi escolhida para investigação a localidade de Cidade Praia situada no bairro Lagoa Azul, em Natal - RN. A escolha deu-se pelo fato dessa localidade se situar em um bairro periférico da cidade e ter disponível o atendimento por transporte público.

Definindo melhor a nossa área de estudo, a localidade de Cidade Praia se localiza no bairro Lagoa Azul, o qual teve seus limites definidos pela Lei $n^{0} .4 .328$ de 05 de abril de 1993, oficializada no Diário Oficial do Estado em 07 de setembro de 1994. O bairro se localiza na Região Administrativa Norte e tem como limites: ao Norte o município de Extremoz; ao Sul os bairros Pajuçara e Potengi; a Leste o município de Extremoz e o bairro Pajuçara; e a Oeste o município de São Gonçalo do Amarante e o bairro Nossa Senhora da Apresentação.

Ao tratar da questão de como ocorre a mobilidade das pessoas residentes na localidade de Cidade Praia, é importante compreendermos o processo de formação do bairro no qual está inserido, quais circunstâncias temporais e espaciais ele se insere no processo de urbanização da cidade do Natal, assim como também compararmos sua configuração socioeconômica relacionada aos demais bairros da cidade do Natal.

É imprescindível destacar que o processo de formação do bairro em questão está atrelado a formação da Zona Norte. Dessa forma, Araújo (2004, p. 27) afirma que “o espaço da Zona Norte não foge então às determinações por que passa o espaço urbano capitalista em seu processo de produção-(re)produção”, visto que em sua formação na década de 1970 já se apresenta como um espaço segregado, pois está inserido no contexto urbano capitalista da cidade do Natal e se constituiu através de um processo de produção desigual.

Segundo Araújo (2004), até a década de 1970 a Zona Norte era um espaço rural onde existia a Vila de Igapó e a Redinha, ambos eram distrito de Natal. Esse contexto rural se mantinha atrelado ao processo de urbanização da cidade. Somente a partir dos anos 1980, devido à expansão horizontal da política habitacional, a cidade atingiu a totalidade de sua urbanização incorporando ao seu tecido urbano as áreas rurais até então existentes.

Tal processo de urbanização de Natal estava inserido no contexto da política desenvolvimentista adotada pelo governo militar que enfatizava a implantação de uma área industrial e de infra-estrutura nos centros urbanos a fim de transformar o país em "Grande Potência” e minimizar as desigualdades regionais (BECKER; EGLER, 1998 apud ARAÚJO, 2004).

O ordenamento da atividade industrial que resultou na criação do Distrito Industrial de Natal (DIN) e a implantação da política habitacional do Sistema Financeiro da Habitação (SFH) marcou a formação do espaço urbano da Zona Norte. Nesse contexto, entre os estados do Nordeste o Rio Grande do Norte era o único que não possuía um distrito industrial. Até então na cidade as atividades industriais não eram separadas dos espaços residenciais, o que ocasionavam problemas urbanos e elevava o preço do solo nas áreas onde se situavam, o que gerou um processo de especulação imobiliária nessas áreas. Como conseqüência, a política habitacional se expandiu nos sentidos norte e sul da cidade. Sendo que foi 
[...] designado à Zona Sul a implantação do "mercado econômico" de habitação, para a população cuja faixa de renda variava entre 6 a 12 Salários Mínimos mensais. Enquanto que coube à Zona Norte o "mercado popular", com uma faixa de renda estabelecida entre 1 a 5 Salários Mínimos mensais” (ARAÚJO, 2004, p. 30 ).

Assim, podemos verificar que a Zona Norte foi ocupada tendo como base um processo de segregação sócio-espacial e de periferização do processo de (re)produção do espaço urbano de Natal. Como o valor do solo na cidade se tornou pouco acessível às camadas populares, formada principalmente de migrantes oriundos do interior do estado, foi direcionado à Zona Norte um mercado popular de habitação para atender a esta demanda.

Desse modo ocorreu o deslocamento de mão-de-obra do campo para a cidade do Natal justamente por comportar o parque têxtil, atrativo para a população migrante. Assim, a Zona Norte absorveu uma significativa parcela dessa população por ofertar o acesso à moradia oferecida pela política habitacional do SFH. A Zona Norte encarregou-se de acolher parte da crescente população de Natal, devido o acesso à moradia, uma vez que as políticas habitacionais deste espaço eram acessíveis à população de baixa renda. No entanto, por não atender aos requisitos como vínculo empregatício e renda, boa parte dessa população ficou à margem desse processo, residindo às margens dos conjuntos habitacionais, produzindo novos espaços urbanos.

Assim percebemos que no espaço urbano da Zona Norte, já segregado em relação a outros espaços da cidade, ocorre outro processo de exclusão ou uma segregação da segregação. Assim, constatamos que essa realidade reproduz, internamente na Zona Norte o mesmo processo de segregação sócio-espacial que esta apresenta quando comparada ao conjunto da cidade do Natal, visto que os novos espaços criados são segregados sócio-espaciais em relação aos conjuntos habitacionais da Zona Norte.

É nesse contexto que se origina o bairro Lagoa Azul, cujo atual arranjo urbano-espacial compreende: os conjuntos habitacionais como núcleos formadores; e as áreas de autoconstrução - vilas, localidades, favelas e comunidades carentes - oriundas da alternativa de moradia daqueles que não tiveram acesso às políticas de habitação. Dessa maneira, com o incremento da política habitacional que abrangeu a Zona Norte foram construídos no espaço de Lagoa Azul os Conjuntos Residenciais: Nova Natal, em 1983, com 2.863 unidades habitacionais; Gramoré, também em 1983, com 1.708; Eldorado, em 1991, com 153; e Cidade Praia com 199 unidades habitacionais, ambos financiados pela Companhia de Habitação Popular do Rio Grande do Norte (COHAB-RN). No bairro são encontradas 05 áreas consideradas subnormais: Eldorado com 81 edificações, Lagoa Azul com 113, José Sarney com 41, Gramoré com 59 e Cidade Praia com 88 edificações (NATAL, 2005a).

A população residente em 2000 era de 50.413 habitantes, sendo o $3^{\circ}$ bairro mais populoso da cidade possuindo uma densidade demográfica em 2000 de 48,33 hab./ha. A taxa média geométrica de crescimento populacional no período de 1991 a 2000 foi de 19,9\%, sendo que em 1991 Lagoa Azul possuía 9.864 residentes; em 1996 passou a ter 40.199; e em 2000 somava 50.413. Tais dados demonstram a maior taxa de crescimento populacional da cidade neste período (NATAL, 2005b). 
Esses dados são relevantes por constatarem que desde a sua fundação o bairro Lagoa Azul, no qual se insere a localidade Cidade Praia, é um dos bairros que absorveram um maior contingente populacional, especialmente no período entre 1991 a 1996, uma vez que a população deu um salto 9.864 residentes para 40.199. Observando as datas das construções dos conjuntos habitacionais também podemos aferir que essa população ocupou as margens destes, nos loteamentos e favelas.

A população residente por sexo é constituída por 24.366 homens e 26.047 mulheres representando respectivamente $48,33 \%$ e $51,67 \%$ da população. A estrutura etária é representada por uma maioria jovem, sendo 45,09\% representada por jovens de 0 a 19 anos. Tais dados demonstram que a maioria dos residentes são jovens, o que vem a gerar uma maior demanda por escolas, espaços de lazer, bem como por trabalho.

Atualmente o bairro Lagoa Azul dispõe de 12.225 domicílios, sendo 99,51\% formados por casas particulares. Deste total, 97,42\% dos domicílios participaram da rede geral de abastecimento de água, mas há apenas 124 domicílios ligados à rede geral de esgotos e os restantes são equipados com fossas sépticas ou rudimentares. Evidenciando a falta de investimento em infra-estrutura de saneamento básico no bairro (NATAL, 2005a).

De acordo com dados da Companhia Energética do Rio Grande do Norte (COSERN) o número de ligações por tipo de uso é o seguinte: residencial - 12.388 (96,13\%); industrial - 40 (0,31\%); comercial - 390 (3,03\%); público - 60 (0,46\%). A telefonia por tipo de uso é a seguinte: residencial - 6.537 (93,08\%); comercial - 127 (1,81\%); público - 359 (5,11\%). Esses dados, demonstrados na tabela 01, são relevantes por demonstrarem que Lagoa Azul se apresenta como bairro predominantemente residencial tendo em vista a finalidade das ligações de energia elétrica e de telefonia.

Dos moradores de Lagoa Azul, 26,57\% recebem até um salário mínimo e 42,10\% possuem rendimento que varia entre 1 a 3 salários mínimos, percentual bem inferior aos que ganham mais de 20 salários mínimos que representa $0,15 \%$ da população. Assim, verificamos que o rendimento médio mensal da maioria da população residente em Lagoa Azul compreende em sua maioria na ordem dos sem rendimentos a 3 salários mínimos, o que nos permite classificá-la como população de baixos rendimentos. Especialmente, quando comparada à cidade como um todo, como demonstra a tabela abaixo.

Tabela 1: Rendimento médio mensal municipal/regional/bairro.

\begin{tabular}{|c|c|c|c|}
\hline ÁREA GEOGRÁFICA & NATAL & ZONA NORTE & LAGOA AZUL \\
\hline $\begin{array}{c}\text { RENDIMENTO MÉDIO } \\
\text { (SM) }\end{array}$ & 6,09 & 2,92 & 2,35 \\
\hline
\end{tabular}

Fonte: NATAL, 2005a.

Comparado ao rendimento médio mensal em salários mínimos do município (6,09\%) e da região administrativa Norte (2,92\%), o bairro de Lagoa Azul (2,35\%) não se encontra muito bem posicionado no que diz respeito à distribuição de renda entre a sua população economicamente ativa. O que revela um quadro socioeconômico bastante preocupante refletido na posição que o mesmo ocupa no cenário municipal, ou seja, o $29^{\circ}$ lugar em distribuição de renda entre os 36 bairros existentes na cidade. De acordo com os dados 
referentes à renda, já foi discutido anteriormente que somente ele não designa se uma pessoa é ou não excluída socialmente, no entanto é um dos indícios dessa situação.

O número de empresas existentes totaliza em 1.157, de modo que, entre estas, as atividades econômicas desenvolvidas em Lagoa Azul são composta em quase toda sua totalidade pela atividade comercial e pela prestação de serviços, preenchendo respectivamente 50,82\% e 40,54\% do total de estabelecimentos existentes no bairro. Apesar de verificarmos um incremento no setor produtivo do bairro, este ainda é insuficiente para absorver a demanda de mão-de-obra existente fazendo com que grande parte da população residente se desloque para outras áreas da cidade que apresentam maior dinamismo nas atividades econômicas, tanto relacionadas ao mercado de trabalho quanto na oferta de bens e serviços.

Com relação ao sistema educacional o bairro dispõe de 31 estabelecimentos de ensino, sendo 12 particulares e 19 públicos. A taxa de alfabetização da população com idade igual ou superior a 05 anos é de 80,53\%, percentual razoável se comparado aos demais bairros da cidade (NATAL, 2005a). Porém, o sistema de ensino oferecido é até o Ensino Médio, quem busca outras modalidades tem que se deslocar para outras localidades, e os que querem e não podem pagar pelo deslocamento não estudam.

Os estabelecimentos voltados à assistência médica no bairro, totalizam 07 unidades de saúde, sendo todas da rede ambulatorial municipal. O que nos permite dizer que aqueles que optarem por um atendimento particular ou mesmo em caso de urgência e emergência, ou necessitarem de maternidade têm que se deslocarem a outros bairros da cidade.

No que se refere aos equipamentos voltados para o lazer existentes no bairro, os dados da Secretaria Especial de Meio Ambiente e Urbanismo (NATAL, 2005a) revelam que Lagoa Azul dispõe de 08 quadras, 09 campos/mini-campos, 08 praças. No entanto, em Cidade Praia só há uma quadra de esportes. Assim as pessoas residentes que buscam o lazer precisam se deslocar, e geralmente utilizam o transporte público, uma vez que os equipamentos existentes são precários e sem infra-estrutura.

Com relação à segurança pública o bairro é carente de entidades de segurança como delegacias distritais, delegacias especializadas e corpo de bombeiros não possuindo nenhuma destas unidades, o que deixa a população desprotegida.

Ao buscar caracterizar Cidade Praia em seus aspectos sócio-econômicos, foi preciso fazêlo tendo como referência o bairro Lagoa Azul, no qual está inserido. Assim percebemos que, de modo geral, o bairro é: um dos mais populosos de Natal; a renda de seus habitantes é uma das menores da cidade; a população economicamente ativa tem que se deslocar, uma vez que o setor produtivo não absorve a mão-de-obra disponível; os equipamentos de lazer são precários; as escolas atendem até o Ensino Médio, limitando muitas vezes as expectativas daqueles que não tem condições financeiras de se deslocar; os serviços de saúde especializados também devem ser buscados em outras localidades. Enfim, mediante estas as informações podemos afirmar que a população dessa localidade é carente de investimentos sociais e que o transporte público é sem dúvida um dos meios de inclusão aos espaços da cidade. 


\section{A OFERTA DE TRANSPORTE COLETIVO EM CIDADE PRAIA}

A localidade Cidade Praia é atendida pelos ônibus oriundos do Conjunto Nova Natal, também localizado no bairro de Lagoa Azul. A cobertura é feita por duas empresas de ônibus: a Guanabara e a Rio Grandense, sendo distribuída em 5 linhas de ônibus: a linha 01, que faz o percurso Cidade da Esperança/Gramoré; a linha 03, que abrange Nova Natal/Campus Universitário; a linha 10, que abrange Nova Natal/Ribeira; a linha 28, cujo itinerário é Nova Natal/CEFET; e a linha 64, com itinerário Nova Natal/Petrópolis. As informações referentes as áreas que estas linhas abrangem, os dias que operam, frota, quantidade de viagens ao dia, o tempo do percurso, a distância, bem como a data de quando começaram a operar estão listados na tabela abaixo.

Tabela 2: Linhas de ônibus que atendem Cidade Praia

\begin{tabular}{|c|c|c|c|c|c|c|c|}
\hline $\mathbf{N}^{\mathbf{o}}$. & Nome da linha & $\begin{array}{c}\text { Data da } \\
\text { permissão }\end{array}$ & Dias & Frota & $\begin{array}{l}\text { Viagens } \\
\text { ao dia }\end{array}$ & $\begin{array}{c}\text { Tempo } \\
\text { (min) }\end{array}$ & $\begin{array}{c}\text { Extensão } \\
(\mathbf{k m})\end{array}$ \\
\hline 01.2 & $\begin{array}{l}\text { Cid. da } \\
\text { Esperança } \\
\text { Gramoré }\end{array}$ & 20/08/1984 & Todos & 08 & 48 & 130 & 49,2 \\
\hline \multirow{2}{*}{10} & \multirow{2}{*}{$\begin{array}{l}\text { Nova Natal } \\
\text { Ribeira }\end{array}$} & \multirow{2}{*}{ 01/07/1983 } & Úteis & 06 & 44 & 105 & \multirow{2}{*}{37,33} \\
\hline & & & Sábados & 05 & 37 & 100 & \\
\hline \multirow[b]{2}{*}{64} & \multirow{2}{*}{$\begin{array}{c}\text { Nova Natal / } \\
\text { Ribeira/Petrópoli } \\
\text { s }\end{array}$} & \multirow{2}{*}{ 16/06/1991 } & Úteis & 10 & 65 & 105 & \multirow{2}{*}{35,38} \\
\hline & & & Sábados & 07 & 51 & 100 & \\
\hline $\begin{array}{l}64 / \\
10\end{array}$ & $\begin{array}{c}\text { Nova Natal } \\
\text { Ribeira/Petrópoli } \\
\text { s P.do Meio }\end{array}$ & 16/06/1991 & Dom./Fer. & 06 & 44 & 100 & 42,46 \\
\hline \multirow{3}{*}{03} & Nova Natal & \multirow{3}{*}{$15 / 10 / 1984$} & Úteis & 13 & 69 & \multirow{3}{*}{120} & \multirow{3}{*}{43,65} \\
\hline & Campus & & Sábados & 09 & 62 & & \\
\hline & Mirassol & & Dom./Fer. & 10 & 48 & & \\
\hline \multirow{3}{*}{28} & \multirow{3}{*}{$\begin{array}{c}\text { Nova Natal } \\
\text { Cefet }\end{array}$} & \multirow{3}{*}{ 29/01/1990 } & Úteis & 06 & 37 & \multirow{3}{*}{90} & \multirow{3}{*}{37,97} \\
\hline & & & Sábados & 04 & 27 & & \\
\hline & & & Dom./Fer. & 03 & 17 & & \\
\hline
\end{tabular}

Fonte: NATAL, 2008a. Disponível em:

$<$ http://www.natal.rn.gov.br/sttu/paginas/servicosonline.asp> $>$. Acesso em 18 fev. 2008

A Empresa de Transportes Guanabara LTDA opera no bairro com as linhas: 01 que possui dois itinerários - o Cidade da Esperança / Parque dos Coqueiros (via Santarém / Gramoré / Nova Natal) e o Cidade da Esperança / Gramoré (via Parque dos Coqueiros / Nova Natal / Santarém). Sendo que o primeiro passa na Avenida Cidade Praia e o outro passa na Avenida Bela Vista, assim quem precisar ir aos locais que esta linha disponibiliza tem que optar por pegá-lo em uma das duas avenidas. Essa questão é incômoda para os moradores de Cidade Praia que tem de esperar o dobro de tempo que as outras pessoas esperam em outros trechos dessa mesma linha.

A referida empresa também disponibiliza a linha 10 - Nova Natal / Ribeira; e a linha 64 Nova Natal / Ribeira - Petrópolis. Com relação a essas duas linhas constatou-se que aos domingos e feriados operam integradas, fazendo o percurso Nova Natal / Petrópolis / Praia do Meio. 
A viação Rio Grandense LTDA cobre a localidade com as seguintes linhas: 03 - esta linha também possui dois itinerários: o Nova Natal / Campus; e o Nova Natal / Viaduto de Ponta Negra. Ambos passam na Avenida Cidade Praia, o trajeto muda apenas na entrada do Campus Universitário. Esta subdivisão também não facilita a mobilidade dos moradores uma vez que, ao invés de acrescentar uma nova linha, divide a existente se tornando um entrave aos que necessitam ir ao Campus, como também para quem vai para o outro itinerário, ocasionando o dobro do tempo de espera. Esta empresa também oferece a linha 28, que faz o percurso Nova Natal / CEFET-RN.

É importante salientar que a linha 01 destina-se à Rodoviária; as linhas 10 e 64 destinam-se especialmente ao Alecrim e ao Centro da cidade, local de comércio e prestação de serviços; e as linhas 03 e 28 destinam-se a Zona Sul, onde se concentram grandes shoppings centers e supermercados da cidade, além de ser uma área de concentração de serviços voltados ao turismo. Dessa forma, percebemos que as linhas disponíveis não abrangem toda a área da cidade e que somente a linha 01 tem um maior itinerário na Zona Norte.

Todas essas linhas fazem conexão com as estações de transferências, mas cada uma em estações diferentes, embora seja uma solução encontrada pela STTU para integrar o sistema de transporte por ônibus, esse serviço deixa a desejar.

Mediante os dados apresentados percebemos que a oferta do transporte coletivo é diferenciada de acordo com os dias da semana: aos sábados, domingos e feriados diminui a frota e o número de viagens. A maior diferença é apresentada pela soma das linhas 10 e 64 que fazem o percurso para o Centro da cidade. Durante a semana as duas linhas somam 109 viagens diárias e aos domingos e feriados esse número diminui para 44 viagens, lembrando que nesses dias essas linhas se integram. Isso nos remete a inferir que se nos finais de semana a população residente pretende sair seguindo este itinerário, vai esperar bastante e pegar o ônibus cheio, o que vem a desestimular o deslocamento.

Enfim, mediante os dados coletados verificamos que há uma carência de infra-estrutura no sistema de transporte em Cidade Praia. Teoricamente há possibilidade de deslocamento para qualquer área da cidade, mas na prática observamos que as condições de uso são diferenciadas, ou seja, a população não tem um serviço de qualidade e podemos verificar essa questão através da opinião das pessoas que utilizam o transporte coletivo.

O contato com os que residem na localidade foi fundamental para a compreensão da importância do transporte, uma vez que para muitas atividades ele é imprescindível, sendo o elo com as oportunidades oferecidas pela cidade. Nesse sentido, a metodologia utilizada consistiu primeiramente em realizar visita exploratória à localidade onde conversas informais com moradores mostravam a importância que o transporte coletivo tem para comunidade e levantamento de dados secundários referentes à população, às características sociais e econômicas e o sistema de transporte coletivo do bairro. Para que a pesquisa fosse exeqüível, foi necessário fazer um recorte espacial do bairro Lagoa Azul, tendo como amostra a localidade denominada de Cidade Praia.

Em um segundo momento, foi realizado um levantamento de dados na Secretaria Municipal de Transporte e Trânsito Urbano - STTU a fim de verificar dados relacionados ao serviço de transporte público e se há políticas públicas de transporte para o bairro em questão. Para este trabalho foi escolhida a pesquisa qualitativa, tendo em vista que o que 
se pretende não é quantificar o fenômeno, mas averiguar a existência deste. Assim, a pesquisa de campo foi realizada em fevereiro de 2008, na localidade citada.

Foram entrevistadas 50 pessoas, escolhidas aleatoriamente, residentes na localidade. A aplicação de questionário foi escolhida para a obtenção de dados referentes à relação entre o entrevistado, residente na localidade, e o transporte público. Iniciando com as necessidades de deslocamento cotidiano e o transporte utilizado, a opinião sobre o transporte público em operação no bairro, se já ocorreu o fato do entrevistado não trafegar pela cidade por algum motivo, entre outros.

Os dados foram coletados através de questionários semi-abertos, contendo questões direcionadas à relação das necessidades de deslocamento do entrevistado e o transporte disponível. Foram coletadas também a opinião e sugestões sobre o sistema de transporte em operação na localidade.

Conforme os dados coletados na pesquisa de campo constatamos que a maioria dos entrevistados (68\%) utiliza o sistema de transporte coletivo, particularmente por ônibus, diariamente. Dos moradores entrevistados 60\% declararam utilizar o transporte coletivo para trabalhar, $28 \%$ para estudar, 64\% para fazer compras, 56\% para lazer e saúde e $8 \%$ para serviços bancários. Estes responderam que utilizam mais de um motivo para o uso do ônibus.

Tais dados demonstram certa dependência de uma parcela dos entrevistados, do transporte coletivo, visto que predomina a função residencial no bairro fazendo com que as pessoas precisem se deslocar para trabalhar e se o transporte público não é eficiente compromete os deslocamentos das pessoas, e por sua vez as oportunidades de trabalho, de estudo, entre outras.

A fim de conhecermos o trajeto diário dos usuários dos transportes coletivos, em Cidade Praia, perguntamos aos entrevistados sobre os locais de trabalho, os quais nos apresentaram da seguinte forma:

Tabela 3: Locais de trabalho dos entrevistados (\%)

\begin{tabular}{|c|c|c|c|c|c|c|}
\hline \multirow{2}{*}{ Bairro } & \multicolumn{4}{|c|}{ Zona Leste } & \multicolumn{2}{c|}{ Zona Sul } \\
\cline { 2 - 7 } & $\begin{array}{c}\text { Cidade } \\
\text { Alta }\end{array}$ & Ribeira & Tirol & Petrópolis & $\begin{array}{c}\text { Ponta } \\
\text { Negra }\end{array}$ & $\begin{array}{c}\text { Lagoa } \\
\text { Nova }\end{array}$ \\
\hline 16 & 36 & 4 & 4 & 4 & 4 & 32 \\
\hline
\end{tabular}

Com base nesses dados podemos confirmar o que já foi dito sobre a característica do bairro ser residencial, onde a maioria para trabalhar precisa se deslocar diariamente para outras regiões da cidade. Embora a Zona Norte venha se desenvolvendo economicamente, os pólos de geração de emprego continuam sendo o Centro da cidade na Zona Leste, região tradicional do comércio e a Zona Sul região onde se localizam os maiores shopping centers e pólo turístico de Natal.

Em relação aos entrevistados que declararam utilizar o transporte coletivo para a locomoção até o local de estudo, a realidade se apresenta da seguinte forma: 
Tabela 4: Locais de estudo dos entrevistados (\%)

\begin{tabular}{|c|c|c|c|c|}
\hline $\begin{array}{c}\text { Conjunto } \\
\text { Santa Catarina }\end{array}$ & Cidade Alta & Lagoa Nova & $\begin{array}{c}\text { Campus } \\
\text { UFRN }\end{array}$ & $\begin{array}{c}\text { Neópolis } \\
\text { UERN }\end{array}$ \\
\hline 14 & 14 & 14 & 44 & 14 \\
\hline
\end{tabular}

Nesse quesito verificamos que a procura por outros bairros para estudar ocorre pelo fato de que o bairro disponibiliza para a comunidade escolas cujo nível atinge até o nível Médio, assim quem procura outros níveis e modalidades, como cursos de nível superior, idiomas, cursinhos, cursos profissionalizantes e de aperfeiçoamento, entre outros, tem que se deslocar para outras áreas da cidade.

O motivo compras foi citado por $64 \%$ dos entrevistados, os quais se deslocam principalmente para o Conjunto Santa Catarina, conforme podemos observar na tabela 07.

Tabela 5: Locais de compra dos entrevistados (\%)

\begin{tabular}{|c|c|c|c|c|}
\hline Bairro & $\begin{array}{c}\text { Conjunto } \\
\text { Santa Catarina }\end{array}$ & Cidade Alta & Alecrim & Lagoa Nova \\
\hline 12 & 32 & 41 & 5 & 10 \\
\hline
\end{tabular}

De acordo com esses dados observamos que embora o setor de comércio seja um dos setores produtivos que mais se desenvolveu no bairro, ainda não satisfaz aos consumidores que procuram outras áreas para realizarem suas compras. Lembrando que para esse quesito foi considerado compras em geral, desde gêneros alimentícios até roupas, entre outras necessidades de consumo.

Entre as pessoas entrevistadas, os principais destinos para tratamento de saúde citados foram os seguintes:

Tabela 6: Locais procurados por motivo de saúde (\%)

\begin{tabular}{|c|c|c|c|c|c|c|}
\hline \multicolumn{3}{|c|}{ Zona Norte } & \multicolumn{3}{c|}{ Zona Leste } & Zona Sul \\
\hline Bairro & $\begin{array}{c}\text { Santa } \\
\text { Catarina }\end{array}$ & Igapó & Petrópolis & Centro & Alecrim & $\begin{array}{c}\text { Lagoa } \\
\text { Nova }\end{array}$ \\
\hline 44 & 12 & 4 & 8 & 16 & 12 & 4 \\
\hline
\end{tabular}

Podemos verificar que, com relação ao motivo saúde, a maioria procura os serviços oferecidos no bairro uma vez que este dispõe de serviços ambulatoriais, mas para urgência e emergência, assim como para maternidade, as pessoas precisam se deslocar para outras localidades já que o hospital mais próximo para essas necessidades é o Hospital Santa Catarina, localizado no conjunto habitacional de mesmo nome. O mesmo acontece para quem prefere atendimento particular ou possui plano de saúde.

No que diz respeito ao lazer, 56\% dos entrevistados declararam se deslocar para o lazer. Os que declararam que não se deslocam muitas vezes querem dizer que não utilizam algum tipo de transporte, preferindo ir a casa de vizinhos e parentes próximo de casa, visto que nas proximidades não há espaços apropriados para o lazer. 
Os locais citados pelos entrevistados estão representados na figura abaixo.

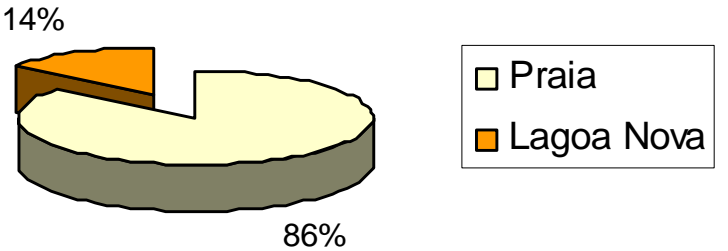

Figura 2: Locais mais procurados para o lazer

Observamos que a opção pelo lazer na praia corresponde à maioria dos entrevistados, no entanto não há linha direta para as praias urbanas. Salientamos que esta opção designa as praias urbanas da cidade, ou seja, Praia da Redinha, do Meio e Ponta Negra; e a opção do bairro Lagoa Nova ocorre porque neste se encontra um dos maiores shopping centers da cidade e o transporte coletivo é mais acessível, pois há duas linhas de ônibus que fazem o percurso, no caso as linhas 03 e 28.

Outro motivo de deslocamento através de ônibus coletivo citado pelos entrevistados foi para utilização de serviços bancários e correios, uma vez que o bairro não possui nenhuma agência bancária e nem serviços de correio. A população recebe correspondência, mas para postagem de cartas, entre outros serviços de correspondência e bancários é necessário se deslocar, visto que as agências mais próximas se localizam no Conjunto Santa Catarina, no bairro Potengi. Com essa informação verificamos que serviços básicos, considerados essenciais atualmente, não são disponibilizados no bairro, embora seja um dos mais populosos da cidade. Tal fato nos permite supor que não é do interesse desse seguimento econômico investir nessa área, uma vez que a população é caracterizada como de baixo poder aquisitivo, o que vem a corroborar com questão de que Lagoa Azul é um espaço segregado.

Ao indagar se o transporte público permite a conexão com todos os espaços da cidade, os dados coletados estão representados na figura abaixo:

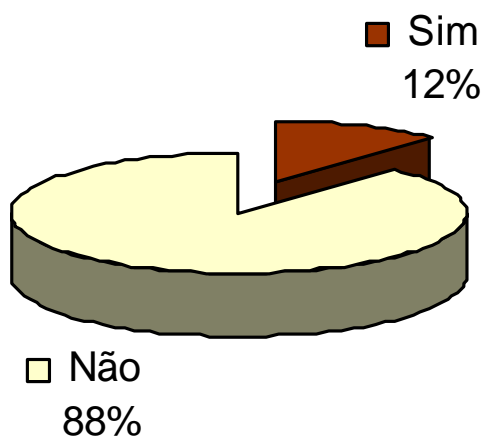

Figura 3: $O$ transporte coletivo possibilita a ida a qualquer lugar da cidade?

Com base nesses resultados verificamos que a conexão com outros bairros da cidade, na concepção dos entrevistados, não é muito boa, de modo que mesmo com a implantação das estações de transferência pela cidade, ao ser indagado se o transporte coletivo disponível possibilita a ida a qualquer espaço da cidade, $88 \%$ dos entrevistados afirmaram que não. 
Pois, segundo estes, para se deslocarem para outros bairros da Zona Norte e a Praia da Redinha, por exemplo, precisam pagar duas passagens e que as estações de transferência precisam ser aprimoradas no que diz respeito à conexão.

Ao serem perguntados se já deixaram de comparecer a algum compromisso por causa do transporte, $86 \%$ afirmaram que sim, sendo os principais motivos: a demora, o ônibus quebrado, a insegurança nos pontos de parada dos ônibus e nos próprios ônibus, o que vem a caracterizar a ineficiência do sistema de transporte oferecido a esta comunidade.

As opiniões sobre a oferta do transporte são pouco variadas, considerando o indicador "ruim" como uma avaliação negativa, a maioria avalia o sistema de transporte nessa ordem, conforme a Figura 4.

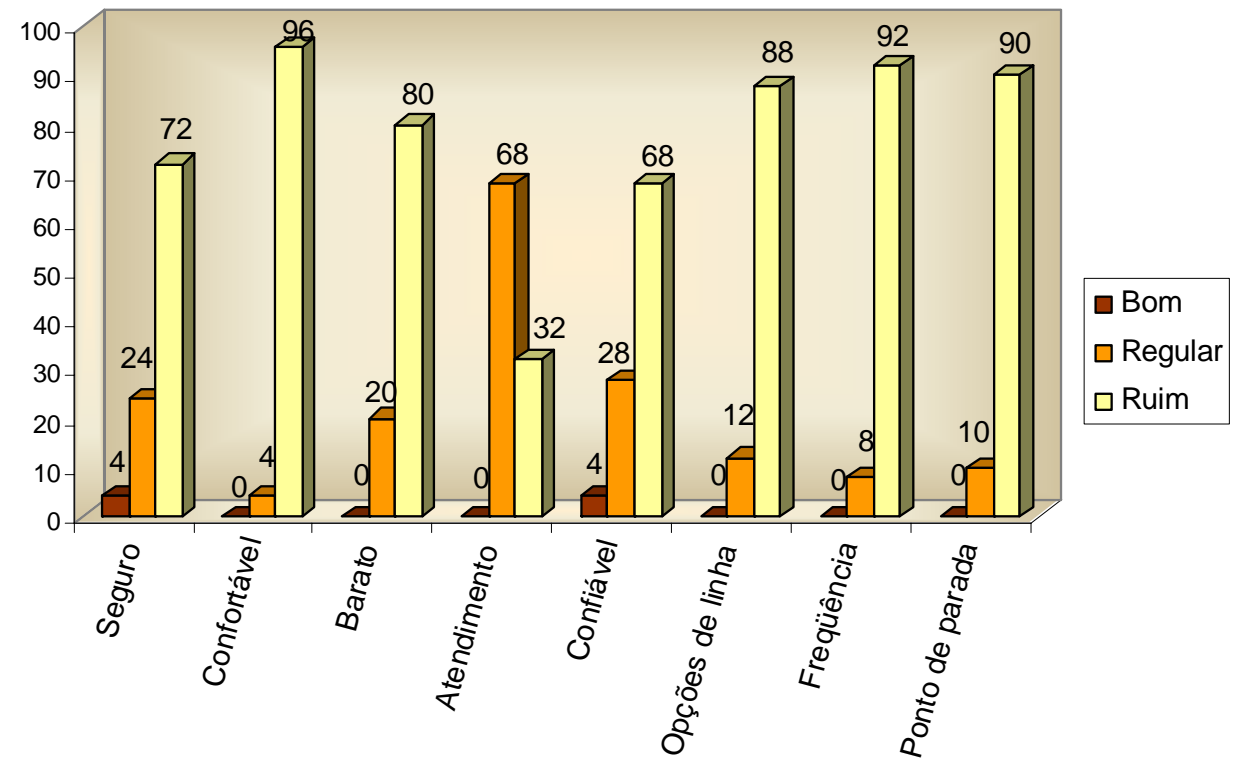

Figura 4: Opinião sobre o transporte coletivo (\%)

Verificamos no gráfico acima a opinião sobre o sistema de transporte coletivo por ônibus na comunidade, nos pontos que dizem respeito à qualidade desse sistema, e constatamos que se apresenta unanimemente como negativa na visão dos entrevistados, o que vem a demonstrar a carência de investimento nesse setor na área de abrangência desse estudo.

O que nos permite afirmar que por se constituir como parte da cidade ilegal, mesmo sendo legítima, conforme Grostein (2001), esse espaço é esquecido pelo poder público, principalmente pelo setor responsável pelo sistema de circulação da cidade. De modo que o serviço não é regulamentado e o que se percebe é que não há empenho em oferecer qualidade neste tipo de serviço e se existe, falta diálogo com a comunidade.

Buscando analisar de modo geral o sistema de transporte coletivo disponível em Cidade Praia, este foi avaliado como péssimo para a maioria conforme a Figura 5 a seguir: 


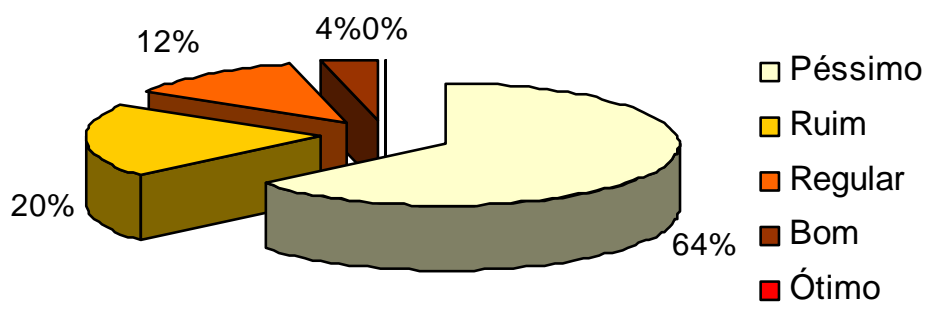

Figura 5: Avaliação do sistema de transporte em Cidade Praia

O resultado desta questão vem corroborar com as questões levantadas anteriormente. Com base nesses resultados podemos dizer que o transporte disponibilizado através dos ônibus coletivo em Cidade Praia é ineficiente, precário e não atende às expectativas e necessidades por parte daqueles que o utilizam, uma vez que a soma dos que acham o serviço ruim a péssimo chega a $84 \%$ dos entrevistados.

Ao serem indagados se já participaram de alguma reunião ou entrevista sobre a situação do transporte no bairro todos responderam que não. E a maioria (92\%) afirma que não conhecem como expressar sua opinião sobre o sistema de transporte da sua comunidade, sendo que $8 \%$ afirmam que existe o telefone da STTU, mas quando ligam não vêem resultado.

As sugestões dadas sobre quais aspectos precisariam melhorar no sistema de transporte coletivo de Cidade Praia, diversas respostas surgiram, entre elas: aumentar o número de linhas, especialmente inter-bairros na Zona Norte, incluindo a Redinha; aumentar o número de ônibus e consequentemente a freqüência para acabar com a superlotação; ônibus novos; limpeza dos ônibus; fardamento dos motoristas e cobradores; mais segurança; proporcionar uma viagem confortável, uma vez que consideram a viagem longa; haver concorrência para que as empresas procurem oferecer um serviço melhor; e que haja fiscalização por parte do órgão responsável no que diz respeito a horários, lotação, poluição emitida, qualidade do ônibus na linha.

Nessa perspectiva, as indagações desse trabalho referem-se ao direito igualitário de ir e vir na cidade tendo como campo de análise a localidade de Cidade Praia. Com base nos resultados coletados, podemos dizer que no bairro Lagoa Azul a oferta de trabalho não é suficiente para atender a demanda da população, as escolas oferecem até o Ensino Médio, não há possibilidade de tratamentos de saúde especializados, não há equipamentos de lazer (somente praças e quadras destituídas de equipamentos que proporcione lazer). O que faz com que grande parte da população precise se deslocar para realizar as atividades inerentes à vida urbana, tendo como principal meio de transporte o ônibus coletivo.

Os resultados da entrevista com os moradores demonstram que nem todas as viagens desejadas podem ser realizadas e as realizadas muitas vezes não são satisfatórias, no que diz respeito aos custos, qualidade, tempo de deslocamento, conforto e até mesmo a perda de compromissos por ineficiência do transporte disponível para esta comunidade. 
Ao averiguar se o transporte público oferece acesso a todos os espaços da cidade, podemos dizer que as estações de transferência existentes atendem em parte o acesso à cidade. Uma vez que a maioria dos entrevistados respondeu que não tem acesso aos bairros circunvizinhos, nem à praia mais próxima, no caso a Praia da Redinha, sendo mais fácil ir à Praia do Meio, embora seja mais longe, lembrando que o transporte disponível só vai aos domingos a esta praia.

Com relação às políticas públicas voltadas para a melhoria da mobilidade da população residente em Cidade Praia podemos citar que o sistema de transporte da cidade oferece a gratuidade, a meia passagem aos estudantes, a tarifa social, lembrando que esses benefícios são custeados pelos que pagam a passagem inteira, portanto não há subsídio por parte do governo. Assim podemos dizer que a camada mais pobre, de um modo geral, que não preenche os requisitos a tais direitos e necessita pagar pelo transporte, acaba financiando parte dos custos dos que tem direito. Ao falar em melhoria da mobilidade não podemos deixar de citar o programa Pró-Transporte, que tem como propósito melhorar a acessibilidade da Zona Norte e consequentemente irá beneficiar os moradores de Cidade Praia.

Enfim, podemos afirmar que moradores residentes em um bairro cujo sistema de transporte público é precário não possuem as mesmas oportunidades se comparado aos residentes em áreas mais privilegiadas, o que se configura em um impedimento no uso pleno aos espaços da cidade, ao direito de ir e vir e ao exercício pleno a condição de cidadão. Desse modo verificamos que a questão da mobilidade não determina a condição de exclusão social de determinado grupo de pessoas, mas se constitui em uma das ferramentas para superação dessa condição.

\section{CONSIDERAÇÕES FINAIS}

Ao longo deste trabalho, buscamos responder às questões que dizem respeito à compreensão dos fenômenos relacionados à mobilidade urbana e a sua relação com a inclusão social no espaço urbano. O processo acelerado da urbanização no país manifestase na metropolização, na favelização e na periferização de grandes contingentes populacionais. Estes fenômenos, amplamente reconhecidos pela literatura geográfica, ainda são os principais desafios para a superação da pobreza e da desigualdade no acesso a serviços públicos e aos equipamentos coletivos.

O estudo do espaço, especificamente o espaço urbano, como importante categoria de análise para a Geografia, não poderia deixar de ser contemplada neste trabalho, uma vez que pretendíamos estudar a mobilidade urbana em um espaço construído, tendo como base a dualidade espacial. Assim, o estudo realizado sobre o espaço urbano capitalista, aliado ao entendimento do processo de urbanização, nos últimos cinqüenta anos, verificado nas cidades brasileiras, particularmente em Natal, revelou que a produção do espaço da localidade de Cidade Praia foi marcada por uma produção diferenciada, tendo em vista o interesse de agentes distintos, caracterizando o fenômeno da segregação socioespacial. Nesse sentido, pode-se afirmar que quanto mais aumenta a ocupação da periferia, a necessidade de deslocamento aumenta proporcionalmente, porém a oferta no setor de transporte público não atendeu à demanda. 
Ao tratar da pobreza percebemos que nem todas as dimensões da pobreza têm sido estudadas e mensuradas no Brasil, sendo necessário incluir entre outras variáveis utilizadas na redução da pobreza a oportunidade de ir e vir no espaço urbano. Assim, ao abordar a questão da pobreza, buscamos um enfoque mais abrangente para o termo, ou seja, o da exclusão social. Uma vez que este conceito inclui, além da insuficiência de renda, a discriminação social, a segregação espacial, a negação dos direitos sociais, entre outros.

Ao relacionar segregação espacial, exclusão social e o fato de haver limitações de acesso fez-se necessário compreender o conceito de mobilidade utilizado nesse estudo. Assim, este consiste na capacidade de um indivíduo se deslocar, envolvendo o desempenho do sistema de transporte, bem como das características do indivíduo e das suas necessidades como renda e tempo. Assim, se a oferta do transporte coletivo não for adequada às necessidades daqueles que dele necessitam, pode se tornar uma barreira à inclusão social e um impedimento ao acesso às oportunidades e atividades essenciais que a cidade disponibiliza. O que nos permite afirmar que este se constitui em um importante elemento de combate à pobreza urbana, pois depende dele o acesso das populações que não dispõem de meios de transporte próprios às oportunidades que a cidade oferece (como trabalho, serviços sociais, e as atividades como o lazer, entre outras).

Nesse intuito, percebemos que o processo de formação de Cidade Praia está ligado a formação da Zona Norte, onde, na década de 1970, já se apresentava como um espaço segregado no contexto urbano capitalista da cidade do Natal, o qual foi originado tendo como base um processo de produção desigual.

Segundo a pesquisa realizada na localidade constatamos que grande parte da população precisa se deslocar para realizar as atividades inerentes à vida urbana, tendo como principal meio de transporte o ônibus coletivo. Que nem todas as viagens desejadas podem ser realizadas, e as que podem muitas vezes não são satisfatórias, devido aos custos, qualidade, tempo de deslocamento e conforto. Que o transporte muitas vezes é ineficiente, ocasionando a perda de compromissos, devido a atrasos, engarrafamentos e ônibus velhos que quebram antes de chegar aos destinos.

A partir das informações adquiridas ao longo deste estudo verificamos que o problema pode ser atenuado a partir da implantação de um sistema de avaliação de serviços, a qual inclua a avaliação dos usuários e a realização de licitação competitiva pelo critério da menor tarifa e maior qualidade, entre outras medidas.

Enfim, verificamos que em locais onde o sistema de transporte público é precário, a população não usufrui das mesmas oportunidades das pessoas residentes em áreas mais privilegiadas, configurando um obstáculo ao uso dos espaços da cidade, ao direito de ir e vir, e ao exercício pleno a condição de cidadão.

Salientamos que a mobilidade urbana não determina a condição de exclusão social de determinado grupo de pessoas, mas se constitui em uma das ferramentas para superação dessa condição. De modo que esta pode ser considerada uma das cinco bases da inclusão social, ou seja, as políticas de inclusão devem agregar além da mobilidade urbana as políticas de emprego e renda, saúde, educação e habitação e que ambas se fortaleçam como política de Estado e não de governos. 
E sem pretender formalizar conclusões, salientamos a importância deste estudo, como mais um trabalho que poderá servir como base para outros que possam vir a surgir sobre a temática dos transportes, visto que ao tratar sobre o tema não devemos esquecer que este diz respeito à pessoas e por conseguinte à (re)produção do espaço.

\section{REFERÊNCIAS BIBLIOGRÁFICAS}

1. ASSOCIAÇÃO NACIONAL DE TRANSPORTES PÚBLICOS - ANTP. Transporte Humano: cidades com qualidade de vida. São Paulo: ANTP, 1997.

2. ARAÚJO, Josélia Carvalho de. Outra leitura do "Outro Lado": o espaço da Zona Norte em questão. 2004. 267 f. Dissertação (Mestrado em Geografia). Programa de Pós-Graduação em Geografia, Universidade Federal do Rio Grande do Norte, Natal, 2004.

3. BRASIL. Lei $\mathrm{n}^{0}$. 10.257, de 10 de julho de 2001. Estabelece diretrizes gerais da política urbana. Disponível em: <http://www.in.gov.br/materia.asp?id=599980> Acesso em: 29 nov. 2007.

4. CARLOS, Ana Fani Alessandri. O espaço urbano: Novos Escritos sobre a Cidade. São Paulo: Labur Edições, 2007, 123p. Disponível em: <http://www.fflch.usp.br/dg/gesp>. Acesso em: 2 jan. 2008.

5. CASCUDO, Luís da Câmara. História da cidade do Natal. Natal: RN Econômico, 1999.

6. CORRÊA, Roberto Lobato. Espaço, um conceito chave da geografia. In: CASTRO, Iná Elias de; GOMES, Paulo César da Costa; CORRÊA, Roberto Lobato (Org.). Geografia: conceitos e temas. Rio de Janeiro. Bertrand Brasil, 1995.

7. _ _ O espaço urbano. Rio de Janeiro: Ática, 1989.

8. GOMIDE, Alexandre de Ávila. LEITE, Sabina Kauark. REBELO, Jorge. Transporte público e pobreza urbana: um índice-síntese de serviço adequado. Brasília: IPEA, 2006 (Texto para discussão, n. 1209). Disponível em: $<$ http://www.ipea.gov.br/sites/000/2/publicacoes/tds/td_1209.pdf $>$. Acesso em: 25 jan. 2007.

9. GOMIDE, Alexandre de Ávila. Transporte urbano e inclusão social: elementos para políticas públicas. Brasília: Ipea, 2003. (Texto para Discussão, n. 960). Disponível em: <http://www.ipea.gov.br/pub/td/2003/td_0960.pdf>. Acesso em: 25 jan. 2007.

10. GROSTEIN, Marta Dora. Metrópole e expansão urbana: a persistência de processos "insustentáveis". São Paulo Perspec., São Paulo, v. 15, n. 1, 2001. Disponível em: $<$ http://www.scielo.br/scielo.php?script=sci_arttext\&pid=S0102-88392001000100003

\&lng=pt\&nrm=iso $>$. Acesso em: 1 Fev. 2007.

11. INSTITUTO DE DESENVOLVIMENTO E INFORMAÇÃO EM TRANSPORTE ITRANS. Projeto mobilidade e pobreza: relatório final. Brasília: ITRANS, 2004.

12. LEMOS, Diana Scabelo da C. P. S. SANTOS, Márcio Peixoto de Sequeira. PORTUGAL, Licínio da Silva. Análise da relação entre o sistema de Transporte e a exclusão social na cidade do Rio de Janeiro. ENGEVISTA, v. 6, n. 3, p. 36-53, dez. 2004. Disponível em: $<$ http://www.uff.br/engevista/3_6Engevista3.pdf $>$. Acesso em: 15 fev. 2007. 
13. LIMA NETO, Oswaldo et al. Transporte no Brasil: história e reflexões. Recife, PE: UFPE, 2001.

14. NATAL. Secretaria Municipal de Meio Ambiente e Urbanismo. Conheça melhor o seu bairro: Lagoa Azul. Natal: Departamento de Informação, Pesquisa e Estatística, 2005a.

15. Anuário Natal 2005. Natal: Departamento de Informação Pesquisa e Estatística, 2005b.

16. . Lei Complementar $n^{\circ}$. 082, de 21 de junho de 2007. Dispõe sobre o Plano Diretor de Natal. Disponível em: <www.natal.rn.gov.br/semurb/legislação/Plano Diretor.pdf >. Acesso em: 26 nov. 2007.

17. Transporte: Ônibus. Disponível em: <http://www.natal.rn.gov.br/sttu/paginas/onibus.php>. Acesso em: 10 fev. 2008.

18. ROLNIK, Raquel. O que é cidade. São Paulo: Brasiliense, 2004.

19. SANTOS, Milton. O espaço do cidadão. 5. ed. São Paulo: Nobel, 2000.

20. Por uma geografia nova: da crítica da geografia a uma geografia crítica. São Paulo: Hucitec,1978.

21. SPOSATI, A. Exclusão social abaixo da linha do Equador. Texto da apresentação no seminário sobre exclusão social realizado na PUC/SP, em abril de 1998. Disponível em: <http://www.dpi.inpe.br/geopro/exclusao/exclusao.pdf> . Acesso em: 16 nov. 2007.

22. TORQUATO, Adriana Maria Soares Cunha. Transporte e exclusão social: investigando conexões em um bairro de Natal-RN. 2006. 178 f. Dissertação (Mestrado em Engenharia Civil), Programa de Pós-Graduação em Engenharia Civil, Universidade Federal de Pernambuco, Recife, 2006. Disponível em: $<$ http://www.bdtd.ufpe.br/tedeSimplificado/tde_arquivos/25/TDE-2006-1120T115925Z-156/Publico/adriana.pdf>. Acesso em: 23 jan. 2007.

23. VASCONCELLOS, Eduardo Alcântara. Transporte urbano, espaço e eqüidade: análise das políticas públicas. São Paulo: Annablume, 2001.

24. XAVIER, Lúcia Rejane de Almeida. Consolidação da Rede Cooperativa de Pesquisa Cidades Interativas: Mobilidade Urbana, Acessibilidade e Governo Eletrônico. In: SEMINÁRIO DE CONSOLIDAÇÃO DA REDE CIDADES INTERATIVAS: experiências, estudos e proposições, 1, 2008, Natal. Anais... Natal: [s.n.], 2008. (Trabalho não publicado). 